Published in final edited form as:

Exp Gerontol. 2008 August ; 43(8): 718-728. doi:10.1016/j.exger.2008.05.0168.05.016.

\title{
Innate immunity and aging
}

\author{
Christian R. Gomez ${ }^{1,2,5,7}$, Vanessa Nomellini ${ }^{1,3,5,6}$, Douglas E. Faunce ${ }^{1,2,4}$, and Elizabeth \\ J. Kovacs $1,2,3,5,6$ \\ 1 The Burn and Shock Trauma Institute, Loyola University Medical Center, 2160 South First Avenue, \\ Maywood, IL 60153, USA
}

2 Department of Surgery, Loyola University Medical Center, 2160 South First Avenue, Maywood, IL 60153, USA

3 Department of cell Biology, Neurobiology, and Anatomy, Loyola University Medical Center, 2160 South First Avenue, Maywood, IL 60153, USA

4 Department of Microbiology and Immunology, Loyola University Medical Center, 2160 South First Avenue, Maywood, IL 60153, USA

5 Immunology and Aging Program, Loyola University Medical Center, 2160 South First Avenue, Maywood, IL 60153, USA

6 Stritch School of Medicine, Loyola University Medical Center, 2160 South First Avenue, Maywood, IL 60153, USA

7 Facultad de Ciencias de la Salud, Universidad Diego Portales, Ejército 141, Santiago, Chile

\begin{abstract}
Advanced age is associated with defects in all of the cells of the innate immune system, including numbers, function, their, and early stages of activation. In this review, the current state of the field on the impact of age on the innate immune system is presented. The analysis of the literature suggests that a dysfunctional innate immune system is a contributing factor to aberrant outcomes after injury or infection and to the development of many of the diseases observed in the elderly. Gaining an understanding of the nature of the defects in innate immune cells may allow the development of therapeutic strategies aimed at restoring innate immune function in aged individuals.
\end{abstract}

\section{Keywords}

Neutrophils; macrophages; NK; NK-T; mast cells; eosinophils; age

\section{Introduction}

Aging is associated with a decline in health, partially attributed to defects in immunity [reviewed in (Katz et al., 2004)]. The complex process of immunosenescence affects both the innate and the adaptive arms of the immune system (Allman and Miller, 2005b; Gomez et al.,

Corresponding author: Elizabeth J. Kovacs, Ph.D., Burn and Shock Trauma Institute, Department of Surgery, Loyola University Medical Center, Building 110, Room 4232, 2160 South First Avenue, Maywood, IL 60153 USA, E-mail: ekovacs@ lumc.edu, Phone: 708-327-2477, Fax: 708-327-2813.

Publisher's Disclaimer: This is a PDF file of an unedited manuscript that has been accepted for publication. As a service to our customers we are providing this early version of the manuscript. The manuscript will undergo copyediting, typesetting, and review of the resulting proof before it is published in its final citable form. Please note that during the production process errors may be discovered which could affect the content, and all legal disclaimers that apply to the journal pertain. 
2005; Weng, 2006). Commonly observed in the elderly are decreased T cell memory, exhaustion of the naïve $\mathrm{T}$ cell population with involution of the thymus (Weng, 2006), decline in B cell production reflected in defective humoral immunity (Allman and Miller, 2005a; Riley et al., 2005), and a chronic inflammatory state that has come to be called, "inflammaging" (Franceschi et al., 2000). As a result, older subjects are less able to mount an immune response following an infectious challenge than are young adults (Linton and Dorshkind, 2004) and more susceptible than young to viral and bacterial infections, opportunistic infections, reactivation of latent viruses, autoimmune diseases, and neoplasias (Effros, 2003; Murasko and Jiang, 2005; Pawelec et al., 2005; Prelog, 2006).

Cumulative evidence indicates that aging exerts significant effects on all cells of the innate immune system (Agrawal et al., 2008; Gomez et al., 2005; Plackett et al., 2004; Plowden et al., 2004a; Sebastian et al., 2005; Solana et al., 2006). Impairment of multiple neutrophil functions, such as phagocytic capacity, synthesis of reactive oxygen intermediates, and intracellular killing efficiency is observed in the elderly (Fulop et al., 2004; Tortorella et al., 2007). Advanced age also affects macrophage functions, including phagocytic activity, cytokine and chemokine secretion, antibacterial defenses, infiltration and wound repair, and antigen presentation (Sebastian et al., 2005). There is contradictory evidence regarding the effects of aging on natural killer (NK) and natural killer T (NKT) cells numbers and functional properties (Mocchegiani et al., 2003; Peralbo et al., 2007). Although studies are limited, mast cell (Hart et al., 1999; Montagna and Carlisle, 1990; Nguyen et al., 2005) and eosinophil (Kasper et al., 1999; Leng et al., 2005; Yagi et al., 1997) numbers and functional properties have also shown age-related alterations. These latter findings are particularly interesting in the context of the age-associated increase in morbidity and mortality with asthma, autoimmune disorders and atherosclerosis. Thus, differences in both the number and function of multiple cell type, contribute to the defective innate immunity with advanced age. Moreover, new evidence has pointed to intracellular molecular pathways that lead to impaired activation of immune cells. We next review, in detail, the age-associated changes in number, function and cell signaling in cells of the innate immune system.

\section{Neutrophils}

Neutrophils are the predominant phagocytes of circulating blood. Typically, they are recruited to the site of infection by chemokines and products released from microorganisms (Chilvers et al., 2000; Davis et al., 1987; Lehrer et al., 1988). Chemotaxis towards the infection, results in adherence of neutrophils to endothelial cells through cell adhesion molecules and ultimately in migration through endothelial walls. The ingestion of pathogens by neutrophils occurs by means of phagocytosis and killing through the generation of reactive oxygen species (ROS) and the release of toxic granular enzymes (Lehrer et al., 1988). Neutrophils are short-lived cells, with a half-life of 8-12 hours and are removed by apoptosis, leading to their recognition and phagocytosis by macrophages (Savill et al., 1989). However, in response to priming agents, such as endotoxin, granulocyte macrophage colony stimulating factor (GM-CSF), platelet activating factor (PAF) and pro-inflammatory cytokines, including tumor necrosis factor-alpha $(\mathrm{TNF} \alpha)$, their life-span is increased, resulting in elevated bactericidal capacity (Chilvers et al., 2000). In addition, this prolongation of the neutrophil life-span can contribute to excessive local tissue damage through the release of proteolytic enzymes, elastase and collagenase, (Sibille and Marchandise, 1993; Sibille and Reynolds, 1990).

The effects of aging on the generation and function of neutrophils is shown in Figure 1. For example, there is consistency in the literature in that advanced age does not modify the total number of circulating neutrophils (Albright and Albright, 2003;Chatta and Dale, 1996). In addition, bone marrow cells from young and aged subjects have similar responses to stem cell stimulants such as granulocyte macrophage colony stimulating factor (GM-CSF) and 
interleukin (IL)-3 (Chatta and Dale, 1996). Chemotaxis of neutrophils primed with GM-CSF towards the formylated tripeptide N-formyl-methionyl-leucyl-phenylalanine (fMLP) and GMCSF is reduced in cells from healthy aged volunteers, relative to their younger counterparts (Fortin et al., 2006; Fulop et al., 2004). As a consequence of the defects in chemotactic activity of neutrophils from the elderly, decreased infiltration at sites of injury should be anticipated (Lord et al., 2001). However, in vivo studies reveal a different picture. In a dermal excisional injury model, for example, comparable neutrophil myeloperoxidase (MPO) activity levels were found in the wound bed and in wound homogenates from young and aged mice (Swift et al., 2001). Moreover, pulmonary inflammation was greater in aged mice at 24 hours after receiving an intraperitoneal injection of lipopolysaccharide (LPS), when compared to young animals (Gomez et al., 2007a). This response was accompanied by higher levels of the neutrophil chemotactic cytokines, macrophage inflammatory protein (MIP-2)/CXCL2 and KC/CXCL1, and elevated levels of interleukin (IL)-1 $\beta$, in the lungs of aged mice receiving LPS, relative to young LPS treated mice (Gomez et al., 2007a). Finally, 24 hours after receiving a 15\% total body surface area (TBSA) burn injury, the lungs of aged mice showed a marked increase in neutrophils, and KC, but no changes in MIP-2 and IL-1 $\beta$, compared to young, burn-injured animals (Nomellini et al., 2008a). Thus, in vivo versus in vitro models produce different outcomes. In addition, comparing the type of insult, the small excisional wound model, which generates only a local response, will likely yield a different magnitude of response than one involving a systemic response like LPS or burn injury.

Neutrophils have a short life-span, consequently, a defect in apoptotic cell death may be a contributor to aberrant function of these cells with advanced age. While spontaneous apoptotic death is not affected by advanced age, the ability of priming agents-such as LPS, granulocytecolony stimulating factor (G-CSF), GM-CSF, IL-6 and steroids- to delay neutrophil apoptosis is significantly impaired in elderly persons (Fortin et al., 2007a; Fulop et al., 1997a; Tortorella et al., 2001; Tortorella et al., 2006). In addition, changes in the ratio of pro- and anti-apoptotic members of the bcl-2 family (Fulop et al., 2002), and defective activation of the Janus kinase (Jak)/signal transducer and activator of transcription (STAT) signaling pathway (Fortin et al., 2007a) have been found in the neutrophils of elderly individuals compared to young subjects. Altogether, these finding suggest that advanced age affects the activation of signaling pathways involved in the rescue of neutrophils from spontaneous apoptotic. The defect in signal transduction pathways coupled to some receptors, which should result in an increased susceptibility to neutrophil apoptosis in the elderly, may be an important contributor of aberrant inflammatory responses during senescence.

Neutrophils from elderly humans are less phagocytic than those from younger adults (Butcher et al., 2001; Lord et al., 2001; Wenisch et al., 2000). Moreover, the respiratory burst has been shown to be altered in neutrophils from aged volunteers, although reports vary depending on experimental conditions (Butcher et al., 2001; Fulop et al., 2004). For example, superoxide $\left(\mathrm{O}_{2}^{-}\right)$and hydrogen peroxide $\left(\mathrm{H}_{2} \mathrm{O}_{2}\right)$ production in vitro by neutrophils from aged humans is decreased (Di Lorenzo et al., 1999; Fulop et al., 1985; Nagel et al., 1982) when compared to cells from young. In contrast, others have reported normal to slightly raised $\mathrm{O}_{2}{ }^{-}$or $\mathrm{H}_{2} \mathrm{O}_{2}$ production in by neutrophils from healthy aged humans stimulated in vitro (Ito et al., 1998; Lord et al., 2001). These apparently contradictory data may be explained by the type of stimuli used, including fMLP along with gram positive and gram negative bacteria (Fulop et al., 2004; Lord et al., 2001). In addition, the timing of the analysis may be a contributing factor. For example, the production of $\mathrm{O}_{2}^{-}$was lower after 24 hours of culture in neutrophils from aged volunteers relative to young subjects, but higher after 48 hours (Fulop et al., 2004). Taken together, these results indicate that age affects the microbiocidal capacity of neutrophils.

In relation to the molecular mechanisms involved in the age-related alterations in neutrophil function, impaired intracellular signaling has been implicated as pivotal contributor. Decreased 
intracellular $\mathrm{Ca}^{2+}$ after fMLP stimulation may help to explain reduced phagocytic ability (Fulop et al., 1997b) decreased bactericidal activity (Wenisch et al., 2000) and eventually the declined chemotaxis and bactericidal capacity of neutrophils from the aged. Similarly, actin polymerization is markedly reduced after stimulation of neutrophils from aged subjects with fMLP or phorbol myristate acetate (PMA) — an activator of protein kinase C (PKC)—relative to young (Rao, 1986). The defective actin depolimerization found in neutrophils from aged volunteers has been associated with impaired $\mathrm{O}_{2}{ }^{-}$production (Piazzolla et al., 1998).

Intracellular signaling following receptor ligation may be responsible for many of the observed changes in neutrophils from aged individuals. First, phosphorylation of extracellular receptoractivated kinase (ERK) mitogen-activated protein (MAP) kinase was lowered in neutrophils obtained from healthy aged volunteers following stimulation with GM-CSF (Larbi et al., 2005). Similar results were found for both MAP kinases ERK and p38 in response to fMLP (Fulop et al., 2004). In addition, the generation of $\mathrm{IP}_{3}$, and diacylglycerol (Lipschitz et al., 1991), as well as the activation of cAMP pathways (Chaves et al., 2007), were decreased in neutrophils from the elderly. GM-CSF-modulated granulopoiesis does not appear to be impaired in the aged, however, a reduction in the ability of neutrophils from the elderly to be primed by GM-CSF or to activate the respiratory burst has been extensively documented [reviewed in (Tortorella et al., 2007)]. Evidence suggests that, at least in elderly humans, decreased signal tyrosine phosphatase-1 (SHP-1) and suppressor of cytokine signaling (SOCS) (Tortorella et al., 2006) are involved in the age-related failure of GM-CSF to stimulate neutrophil function via inhibition of phosphoinositide 3-kinase (PI3-K)/ERK and signal transducer and activator of transcription (STAT) pathways (Tortorella et al., 2006). Triggering receptor expressed on myeloid cell-1 (TREM-1) is a receptor with important roles in diverse neutrophil properties, such as phagocytosis, respiratory burst and degranulation (Radsak et al., 2004), as has been demonstrated in neutrophils obtained from aged humans. Following TREM-1 engagement, neutrophils from aged donors had diminished respiratory burst relative to that of neutrophils from younger donors (Fortin et al., 2007b). In addition, the phosphorylation of TREM-1 effectors, such as AKT and phospholipase C- $\gamma$, was also altered with aging (Fortin et al., 2007b). In summary, alteration in intracellular signaling following receptor ligation is a candidate to explain decreased functionality in neutrophils from the elderly.

Toll-like receptors (TLR) 2 and 4 can recognize components of the bacterial cell wall such as peptidoglycans and lipopeptides (TLR2) and LPS (TLR4). The levels of expression of TLR2 and TLR4 on neutrophils are not affected by age (Fulop et al., 2004). However, when the distribution of TLR4 between lipid raft and non-raft fractions at the basal levels and after LPS stimulation was studied, neutrophils from aged donors showed differential recruitment of the receptor to lipid rafts when compared to cells from young donors (Fulop et al., 2004).

Furthermore, a recent publication has demonstrated that, following TREM-1 activation, neutrophils from the aged failed to recruit TREM-1 to lipid rafts (Fortin et al., 2007b). Overall, these data suggests that changes in membrane fluidity seen with age could provide a general mechanism for many of the dysfunctional signaling pathways seen in neutrophils from the elderly (Larbi et al., 2008).

\section{Macrophages}

Monocytes originate from hematopoietic cells in the bone marrow in response to growth factors, such as macrophage-colony stimulating factor (M-CSF), GM-CSF and IL-3 (Barreda et al., 2004). After entering the blood from the bone marrow, monocytes continue to differentiate into macrophages as they migrate into tissues. Macrophages have specific functions depending on the tissue in which they reside: macrophages in secondary lymphoid organs (spleen, lymph nodes, etc.) phagocytose effete red blood cells (spleen) or lymph antigen 
and debris, alveolar macrophages phagocytose dust/bacteria and surfactant, Kupffer cells reside in liver sinusoids and clear particulate matter, microglial cells in the brain clear debris in the central nervous system, osteoclasts in bones participate in bone resorption and remodeling (Albright and Albright, 2003). In general, macrophage functions involve phagocytosis of antigens, microorganisms and cellular debris, and killing of invading microorganisms and tumors through oxygen-dependent and -independent mechanisms (Underhill and Ozinsky, 2002). In addition, macrophages secrete cytokines, which, in turn, play a role in regulation of multiple immune functions, especially inflammatory responses (Albright and Albright, 2003). Each of these functions is enhanced when macrophages are activated from their resting state by a variety of stimuli, including exposure to microorganisms and cytokines (Martinez et al., 2008). In conclusion, macrophages are highly versatile cells with a broad range of functional capabilities that may be affected by senescence.

Macrophages show effects of advanced aged in many of their biological properties (Figure 2). While some reports have shown decreased chemotaxis and phagocytosis in macrophages from aged humans and mice (De La Fuente, 1985;Fietta et al., 1993), other studies using aged rats have found completely opposite results (Corsini et al., 2005;Hilmer et al., 2007) or even no age-related effects (Miller et al., 2007). These differences may reflect the activation state of the macrophages, their source, or particular experimental conditions (Plowden et al., 2004a). Additionally, relative to macrophages from young mice, those from aged mice have decreased capacity for antigen presentation (Plowden et al., 2004b;Solana et al., 2006). These results have been associated with decreased expression of MHC class II molecules (Herrero et al., 2002). This compromise in chemotaxis with advanced age is also observed in other professional antigen presenting cells, such as dendritic cells (Plackett et al., 2004).

With advanced age skin is affected, and these changes have implications for its functions as a protective barrier, including its ability to heal wounds (Gosain and DiPietro, 2004).

Macrophages play an important role during the inflammatory phase of wound healing, as they keep the wound bed free from infection and promote angiogenesis (Barbul and Regan, 1995). Studies performed in mice have demonstrated defective wound healing (Danon et al., 1989; Swift et al., 2001) associated with decreased percentage of phagocytic macrophages (Swift et al., 2001), as well as impaired macrophage function (Danon et al., 1989; Swift et al., 2001). Following a laser injury to the retina, ocular macrophages from aged mice, relative to those from young mice, exhibited an impairment of their anti-angiogenic responses, as evidenced by their incapability to inhibit choroidal neovascularization (Kelly et al., 2007). Compared to young animals, macrophage-rich retinal lesions in aged mice had significant downregulation of TNF $\alpha$, IL-6, IL-12, IL-23, and FAS mRNA, as well as upregulation of IL-10 mRNA (Kelly et al., 2007). The results from this study suggest inability of ocular macrophages from aged mice to regulate angiogenesis. The lack of production of anti-angiogenic surveillance activity by macrophages may help to explain the higher susceptibility of aged individuals to age-related macular degeneration and certain cancers (Kelly et al., 2007).

There is not clear evidence with regard to age-dependent effects on the generation of macrophages from their monocyte precursors (Sebastian et al., 2005). While the number of blood monocytes does not appear to be changed with age, a reduction in cellularity, increased apoptosis, and decreased percentage of macrophages was reported in the bone marrow from aged volunteers (Ogawa et al., 2000). In addition, evidence from studies in bone marrow stromal cells obtained from aged mice support an age-associated impairment in insulin growth factor-1 (IGF-1) signaling, normally involved in recruitment of osteoclasts to the bone marrow surface (Cao et al., 2007). However, contradictory results have been found in other studies. Stromal/osteoblastic cells regulate the number and activity of osteoclasts through expression of growth factors, such as receptor activator of nuclear factor-kappa B (NFkB) ligand (RANKL), M-CSF, and osteoprotegerin (OPG) (Teitelbaum and Ross, 2003). In one study, 
Cao and collaborators found that OPG expression gradually decreased with advanced age in stromal/osteoblastic cells from aged mice, however, RANKL and M-CSF expression increased (Cao et al., 2005). When cultured ex vivo, stromal/osteoblastic cells from aged animals had a greater ability to recruit and stimulate the growth of osteoclasts and exhibited a higher expression of M-CSF mRNA, relative to young animals (Cao et al., 2005). The results from this study suggest that there are increased macrophage progenitors in the bone marrow of aged mice relative to young animals. Further studies are needed to establish the effects of aging on proliferation and differentiation of macrophages' precursors, as well as the involvement of stromal cells on age-associated pathology, such as osteoporosis.

The effects of age on other tissue macrophage populations has also have been studied. For example, advanced age resulted in an increased frequency of Kupffer cells in rat livers (Hilmer et al., 2007). There is controversy regarding whether age alters phagocytic activity by those cells (Hilmer et al., 2007; Videla et al., 2001; Vomel et al., 1981; Yamano et al., 2000). The observed differences may be derived from the use of various methods, e.g. colloidal carbon vs. polystyrene microspheres, to assess the uptake of particles by sinusoidal cells. While no age-related differences were reported in microglia in specific regions of hippocampus of brains from male mice (Long et al., 1998), greater numbers of microglia were found in aged females animals compared to young females (Mouton et al., 2002). Moreover, female mice had 25$40 \%$ more microglia in dentate gyrus and field CA1 of Ammon's horn (CA1) regions than agematched male mice (Mouton et al., 2002). These age and sex-specific defects could be originated as a consequence of the effects of sex hormones and reproductive aging (Gomez et al., 2008b). Despite of these divergent observations, the age-associated changes in number and function of resident macrophages may contribute to increased morbidity and mortality associated with pathogens, as well as to the development of age-associated pathology.

For the most part, aging has been generally associated with increased intracellular levels and activity of the enzyme, cyclooxygenase-2 (COX-2) (Wu et al., 2001), however, there are contradictory data. Following inhalation of air borne particulate matter and inhaled gases, greater lung and systemic effects, such as spontaneous cardiac arrhythmias, are observed in aged rodents, relative to their younger counterparts (Elder et al., 2000; Nadziejko et al., 2004; Sunil et al., 2007). In one study, after inhalation of an aerosol containing ozone reaction products (present in cleansers and air fresheners), the levels of COX-2 protein were reduced in alveolar macrophages obtained from aged rats (Sunil et al., 2007). This diminution may be a potential contributor to the increased susceptibility in the elderly to air pollutants. The reported elevation in COX-2 levels has been linked to an increase in one of its products, prostaglandin $\mathrm{E}_{2}\left(\mathrm{PGE}_{2}\right)$ (Wu et al., 2001). In aged mice, overproduction of $\mathrm{PGE}_{2}$ by $\mathrm{NP}(366-$ 374) peptide (ASNENMDAM)-pulsed, thioglycollate-elicited peritoneal macrophages leads to inhibition of MHC class II expression and IL-12 synthesis in CD8 ${ }^{+} \mathrm{T}$ cells (Plowden et al., 2004b). In general, prostaglandins are described as immunosuppressive because they attenuate lymphocyte proliferation and cytokine production by $\mathrm{T}$ cells and macrophages (Hilkens et al., 1996). Thus, the increase in the release of $\mathrm{PGE}_{2}$ by macrophages from aged individuals could play a role in the observed suppression of $\mathrm{T}$ cell function.

The effects of aging on cytokine production by macrophages have showed conflicting results with stimulation of purified macrophage populations in vitro versus systemic exposure in vivo. For example, performing in vitro studies, we and others reported that macrophages from aged mice produce less TNF $\alpha$ and IL- 6 after exposure with LPS than comparably stimulated cells from young mice (Boehmer et al., 2004; Boehmer et al., 2005; Chelvarajan et al., 2005; Chelvarajan et al., 2006; Renshaw et al., 2002). This observation is consistent regardless of the source of macrophages, either thioglycollate-elicited peritoneal exudates cells (Boehmer et al., 2004; Renshaw et al., 2002) or splenic macrophages (Boehmer et al., 2005; Chelvarajan et al., 2005; Chelvarajan et al., 2006). 
Despite the general agreement about decreased cytokine production by macrophages from aged rodents, studies carried out in monocytes obtained from humans have shown discordant results. The levels of the pro-inflammatory cytokines, TNF $\alpha$ and IL-6 (Delpedro et al., 1998), and chemokines, IL-8 (Clark and Peterson, 1994), RANTES and MIP-1 $\alpha$ (Mariani et al., 2002) were elevated in peripheral blood monocytes from the elderly after in vitro stimulation with LPS. However, evaluation of intracellular cytokines in peripheral blood monocytes (van Duin et al., 2007) revealed defective TLR1/2-induced TNF- $\alpha$ and IL-6 production with advanced age (van Duin et al., 2007). In spite of this, cytokine production following ligation of TLR2/6, TLR4, and TLR5 remained largely intact (van Duin et al., 2007). These differences were maintained even after correcting for variables including gender, race, medications, and comorbidities (van Duin et al., 2007). Inconsistencies between these results and those in aged animals could be related to the species employed in the studies, the maturity of the cells (fully differentiated tissue macrophages versus blood monocytes), or the methodological approaches used for the assessment of cytokine production. To complicate this further, in vivo evidence documents the presence of "inflamm-aging" in healthy aged subjects (Franceschi et al., 2000; Johansen et al., 2008; Salvioli et al., 2006), and elevated inflammatory response after an infectious challenge or injury in both humans and animal models (Gomez et al., 2006b; Gomez et al., 2007a; Krabbe et al., 2004; Martin et al., 2006; Nomellini et al., 2008a; Saito et al., 2000; Saito et al., 2003; Tateda et al., 1996). Since macrophages may be a source of proinflammatory cytokines in vivo, many possible explanations for this inconsistency have been proposed (Gomez et al., 2005). Among the multiple possibilities, the effect of the local environment in vitro versus the effect of the aged microenvironment in vivo should be considered.

Macrophages are exposed to a variety of agents (including hormones, cytokines, chemokines, adrenergic and cholinergic agonists, fatty acids, hormones and immunoglobulins), which can affect their functional and phenotypic characteristics (Stout et al., 2005; Stout and Suttles, 2005). As many of these agents change in quantity with advanced age, the in vivo function of macrophages can profoundly be affected. Thus, the age-specific microenvironment could play a key role in defining the functionality and activation properties of macrophages. We reported that serum from aged rats increased the levels of IL- 6 by thioglycollate-elicited peritoneal macrophages obtained from young animals, cultured in vitro without stimulants (Gomez et al., 2006a). These observations suggest that the elevated production of inflammatory mediators in the aged results, in part, from the interaction of macrophages with their external milieu.

The effect of the aged-specific microenvironment has also been analyzed. In a recent study $\mathrm{Wu}$ et al. analyzed the levels of inflammatory mediators in the adipose tissue from aged mice (Wu et al., 2007). Higher levels of expression of the mRNA for pro-inflammatory cytokines IL-1 $\beta$, IL- 6 and TNF $\alpha$, and lower expression of the anti-inflammatory, peroxisome proliferatoractivated receptor-gamma (PPAR- $\gamma$ ) were found in adipose tissue from aged mice, relative to those of young mice (Wu et al., 2007). The numbers of macrophages in adipose tissue were comparable between young and aged mice, as well as their ability to produce cytokines in vitro (Wu et al., 2007). However, adipocytes from aged mice produced more of these inflammatory mediators than those from young mice (Tchkonia et al., 2007; Wu et al., 2007). Moreover, conditioned medium from adipocytes of aged mice increased cytokine production by peritoneal macrophages from aged mice significantly more than that from adipocytes from young mice (Wu et al., 2007). Altogether, these data suggest that the inflammatory state developed in adipose tissue obtained from aged mice is regulated primarily by adipocytes. In addition, the contribution of macrophages to the inflammatory state may be a product of their interaction with cellular components of the aged microenvironment.

The microenvironment in aged subjects can also contribute to other facets of macrophages phenotype. The heterogeneous population of macrophages can develop into two subsets: 
classically (M1) or alternatively (M2) activated macrophages (Mantovani et al., 2002). The development into one or another phenotype depends on the presence of factors, such as cytokines, specific pathogen-associated molecular patterns, endogenous danger signals, immune complexes, apoptotic cells and hormones (Martinez et al., 2008). Age may impact the polarization of macrophages towards either the M1 or M2 phenotype (Dace and Apte, 2008). For instance, the decrease in production of TNF- $\alpha$, IL-1 $\beta$, IL- 6 and IL-12 (Boehmer et al., 2004; Boehmer et al., 2005; Chelvarajan et al., 2005; Chelvarajan et al., 2006; Renshaw et al., 2002) observed in macrophages from aged mice stimulated in vitro with LPS, contrasted with an elevated IL-10 production (Boehmer et al., 2005; Spencer et al., 1996). This secretory profile, characteristic of a M2 phenotype (Martinez et al., 2008), can lead to an antiinflammatory phenotype. Interestingly, when we studied in vitro cytokine production by splenic macrophages obtained from wild type (WT) vs. IL-6 knockout (KO) mice in response to LPS, the cells from aged IL-6 KO mice had a cytokine production that was similar to that of young WT animals (Gomez, C.R. and Kovacs E.J., unpublished observations). These results suggest that IL-6, an important component of the age-associated microenvironment and may play a role in regulating the age-dependent defects in macrophages.

The classical way of activating macrophages involves stimulation with LPS, or IFN- $\gamma$ (Celada and Nathan, 1994). As with neutrophils, defects in various signaling pathways can be found in macrophages from aged individuals. The impact of aging on macrophage signaling through the IFN- $\gamma$ receptor-mediated signal transduction pathway has been examined. No age-related differences in surface expression of IFN- $\gamma$ receptor in caseinate-elicited peritoneal macrophages from mice has been reported (Ding et al., 1994). However, a marked reduction in total active STAT- $1 \alpha$ protein and a complete inhibition of STAT-1 gene expression in response to IFN- $\gamma$ was reported in peritoneal macrophages from aged compared to young mice (Yoon et al., 2004). The incapacity of macrophages from aged mice to express and activate STAT- $1 \alpha$ could affect the ability to initiate the transcription of specific targets of IFN- $\gamma$ stimulation (Yoon et al., 2004). However, we have failed to correlate this observation using the production of cytokines as parameters of activation after IFN- $\gamma$ stimulation in splenic macrophages from aged mice (E.D., Boehmer, and E.J., Kovacs, unpublished observations). Thus, more studies are needed to confirm the validity of the initial observation.

In addition to its function as the receptor for LPS, TLR4 also binds endogenous ligands, such as oxidized low-density lipoproteins and A $\beta$ peptide (Fassbender et al., 2004; Mullick et al., 2006). While the expression of TLR4 on macrophages from aged mice does not appear to change with age (Boehmer et al., 2004; Boehmer et al., 2005; Chelvarajan et al., 2005; Chelvarajan et al., 2006), surface levels of CD14, a co-receptor for TLR4 (Ingalls et al., 1999 ) were reduced in macrophages from aged animals when compared to those from young mice (Chelvarajan et al., 2005; Vega et al., 2004). Recently, the effect of advanced age on the surface expression of TLRs 1, 2, and 4 was evaluated in peripheral blood monocytes from human volunteers (van Duin et al., 2007). The study excluded immuno-compromised individuals and those who reported symptoms of recent infection. In addition, a repeated measures mixed effects statistical model allowed the evaluation of the effect of age, while accounting for heterogeneous baseline individual differences (van Duin et al., 2007). Relative to those of young adults, TLR1 surface expression levels were lower on monocytes of older subjects, TLR2 surface expression was not affected by age, and only a small decrease in expression was observed for TLR4 in the older group (van Duin et al., 2007). Overall, these observations suggest that proximal components of macrophage signaling cascades are affected by advanced age.

Studies aimed at analyzing the effects of age on the activation of intracellular signaling pathways have documented additional defects in macrophages from aged relative to young mice. For example, a reduction in the levels of the MAP kinases ERK, p38 and JNK was 
reported in macrophages from aged mice relative to young before and after LPS stimulation (Boehmer et al., 2004; Boehmer et al., 2005; Chelvarajan et al., 2006). Alveolar macrophages obtained from young rats, expressed the p56 and p54 isoforms of JNK, whereas those from older rats expressed the p54 and p46 isoforms (Sunil et al., 2007). In this same study, following inhalation of limonene ozone reaction products, alveolar macrophages from young rats increased their ERK levels, whereas ERK expression was decreased in cells from aged animals (Sunil et al., 2007). From these report, it can be concluded that levels and the isoform expression for MAP kinases are affected in macrophages from aged animals.

Activation of macrophages triggers additional signal pathways that have been found to be altered in cells from aged individuals. Examples of this include the decreased plasma membrane translocation of PKC- $\alpha$, PKC-/ $\beta \mathrm{I}$, and PKC- $\beta \mathrm{II}$ in monocytes obtained from aged humans (Delpedro et al., 1998), as well as the increased cytoplasmic degradation of inhibitory $\kappa \mathrm{B}$

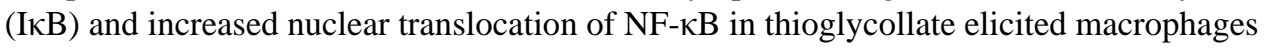
from aged mice (Wu et al., 2003). Decreased expression (Chelvarajan et al., 2006) or activation (Sunil et al., 2007) of members of the NF-kB pathway has also been found in cells from older rodents. Microarray analysis performed on RNA from resting and LPS-stimulated splenic macrophages from young and aged mice showed down-regulated expression of signal transduction genes involved in the TLR-signaling pathway leading to NF- $\kappa \mathrm{B}$ activation (Chelvarajan et al., 2006). These signaling components include the adaptor molecule, MyD88,

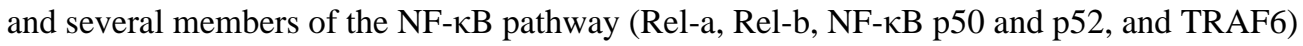
(Chelvarajan et al., 2006). Moreover, an increase in the expression of IL-1 receptor-associated kinase 3 (IRAK3), a negative regulator of this pathway was found in splenic macrophages from aged animals relative to young (Chelvarajan et al., 2006). These new data add to the story demonstrating age-related defects in cell signaling, and suggest that the TLR-dependent pathways are working at reduced efficiency in macrophages from the aged. Those alterations represent mechanisms that could be responsible for the age-associated defects in macrophage function, such as cytokine dysregulation, altered wound healing or decreased cellular response to bacterial infections.

\section{NK and NKT cells}

Within the immune system, NK cells play a significant role in defense against a broad variety of infections and in the inhibition of tumor growth and metastases. Although a number of studies have investigated the effects of age on NK cell number and function in both rodents and humans, there remains considerable controversy about whether advanced age adversely affects NK cell function (Table 1). Earlier studies by Albright and Albright demonstrated that the NK cell activity demonstrable in rodents at 8 weeks of age was nearly absent in mice that were 25 months of age (Albright and Albright, 1983). In humans, however, it has been shown that NK cell cytotoxicity is well preserved in centenarians and that an increase in the actual number of NK cells can be observed in healthy aging (Franceschi et al., 1996; Franceschi et al., 1995; Sansoni et al., 1993). In disease states, however, age-associated alterations in NK cell kinetics and function have been reported and include diminished proliferation rates (Zhang et al., 2007), association with higher incidences of infection (Ogata et al., 1997), onset of atherosclerosis (Bruunsgaard et al., 2001), and increased susceptibility to nutritional deficiencies (Ravaglia et al., 2000).

The discrepancy over the effects of age on NK cell number and function has arisen due to a combination of reports that either do or do not adhere to the SENIUR protocol and other age and disease parameters (Mocchegiani and Malavolta, 2004). When a more restrictive selection criteria is followed, such as the guidelines followed by the SENIUR protocol, it appears that there is an age-related increase in the overall numbers of circulating NK cells in humans (Mariani et al., 2001; Ogata et al., 1997; Solana and Mariani, 2000). However, despite the 
increased number, as the age of the subject being considered advances, there appears to be a modest decline in cytotoxic ability of NK cells toward NK-sensitive targets in vitro (Mysliwska et al., 1992a; Mysliwska et al., 1992b; Ogata et al., 1997), while NK cell antibody-dependent cell-mediated cytotoxicity appears intact (Fernandes and Gupta, 1981). Additional reports have indicated that NK cells from aged subjects exhibit a modest impairment in their ability to produce IFN $\gamma$ and proliferate in response to IL-2 (Borrego et al., 1999). Further studies are needed to further clarify age-related alterations on NK cell function in vivo.

Unlike NK cells, NKT cells are innate lymphocytes that express an $\alpha \beta \mathrm{T}$ cell receptor that recognizes glycolipid antigens presented in the context of CD1d molecules that are expressed on professional antigen presenting cells (Bendelac et al., 2007; Joyce, 2001). NKT cells are found throughout the lymphoid compartment, in the circulation, and comprise the majority of hepatic lymphocytes. They are a rare cell, only constituting about $1 \%$ or less of the total lymphocyte pool. Classified as innate lymphocytes (because they express a highly invariant TCR that recognizes lipids instead of peptides), NKT cells are known for their critical importance in the clearance of viral and bacterial infections as well as facilitating anti-tumor immunity and regulating immune tolerance and autoimmunity (Bendelac et al., 2007; Joyce, 2001). Only a limited number of studies have examined the effects of aging on NKT cell number and function (Table 1), although studies do exist both in mice and humans. In general, it is accepted that as age advances, the absolute number of NKT cells within the lymphoid compartment increases (Dubey et al., 2000; Faunce et al., 2005; Ishimoto et al., 2004; Poynter et al., 1997). It is not clear however, whether the increase results from a longer life-span of NKT cells (vs. conventional lymphocytes) (Berzins et al., 2006), active expansion of the population within the aged immune microenvironment, or perhaps an age-related alteration in recruitment from the peripheral circulation to the lymphoid compartment. Interestingly, several reports have shown an age-related decrease of CD1d-restricted NKT cells in the peripheral circulation as well as decreased proliferative capacity (DelaRosa et al., 2002; Peralbo et al., 2007; Peralbo et al., 2006), which might support the notion that aging causes differential trafficking of the NKT cell population. Although they should not be confused with canonical invariant TCR-expressing NKT cells (i.e., V $\alpha 24-\mathrm{J} \alpha \mathrm{Q}$ TCR), it has been reported that NKTlike cells (non-CD1d-restricted, but still expressing CD56 and other NK-associated molecules) are in fact, elevated in the peripheral circulation (Peralbo et al., 2007).

Although NKT cells are known for their capacity to influence both antigen presenting cell and T cell function, only a few studies have examined the contribution of NKT cells to immunosenescence. Systemic inhibition of NKT cell activation significantly prevented the age-associated decline of both in vitro $\mathrm{T}$ cell proliferative responses and in vivo delayed type hypersensitivity responses (Faunce et al., 2005). In these studies, it was further reported that NKT cells contributed to the age-associated increase of the immunosuppressive cytokine, IL-10 (Faunce et al., 2005). Additional reports demonstrated that NKT cells contribute to the age-associated increase in IL-4, a cytokine that is known to directly inhibit various aspects of T cell immunity and antigen presenting cell function (Faunce and Palmer, 2008; Poynter et al., 1997), while other work demonstrates an age-related decrease in IFN $\gamma$ (Mocchegiani and Malavolta, 2004). Lastly, it has also been shown that age negatively affects NKT cell-mediated cytotoxic activity in mice (Mocchegiani et al., 2004; Tsukahara et al., 1997). Although NKT cells have been shown to play a significant role in shaping the overall immune response and advanced age appears to alter NKT cell number and function, more research is required in both experimental animal models and humans to fully appreciate the impact of aging on NKT cell biology and further understand the mechanisms by which NKT cells might contribute to immunosenescence. 


\section{Mast cells}

Mast cells have wide tissue distribution including epithelia, blood vessels, nerves, the airways and gastrointestinal tract, smooth muscle cells and mucus-producing glands (Galli et al., 2005). In some species, including mice, mast cells also reside within mesothelium-lined cavities, such as the peritoneal cavity (Finlay-Jones et al., 1999). Upon activation-for example via aggregation of the Fc\&RI - mast cells can produce a vast array of mediators, chemokines, and cytokines with pro-inflammatory, anti-inflammatory, and/or immunomodulatory effects (Galli et al., 2005)

The effect of advanced age on the number of mast cells has been studied (Table 1). A decrease in mast cells was reported in the skin of aged humans (Montagna and Carlisle, 1990). Meanwhile, an age-associated increase in the numbers of dermal mast cells was found in BALB/c (Hart et al., 1999), but not C57BL/6 (Hart et al., 1999;Nguyen et al., 2005) mice. Interestingly, no changes were reported in the number of mast cells in lamina propria cells in the jejunum biopsy specimens collected from elderly patients with gastrointestinal symptoms, but no evidence of immunological, infectious, neoplastic, or allergic disease (Arranz et al., 1992). Thus, the number of mast cells in aged individuals depends on the tissue source and the species under analysis.

In addition to their roles in the initiation of adaptive immune responses (McLachlan et al., 2003), bacterial (Di Nardo et al., 2003) and antiparasitic clearance (Furuta et al., 2006; McDermott et al., 2003), and the promotion of inflammatory responses (Nigrovic et al., 2007), mast cells are also involved in numerous inflammatory diseases, including autoimmune disorders and atherosclerosis (Metz and Maurer, 2007; Nigrovic et al., 2007). As many of these disorders are more frequent in the elderly, it is intriguing to speculate how the dysregulations in mast cell function may contribute to the development of these pathologies. As an example, an increase in mast cell number and degranulation was reported with aging in patients subjected to aortocoronary bypass and undergoing varicose vein surgery (Pascual et al., 2007). In addition, enhanced mature transforming growth factor beta -1 (TGF- $\beta 1$ ) correlated with age and with the varicose condition (Pascual et al., 2007). The authors of this publication have speculated that mast cells, as sources of proteases (Galli et al., 2005), could be major contributing factors to the cleavage or maturation of TGF- $\beta 1$. As increased mast cells and TGF$\beta 1$ contribute to failure of the vein wall, this study suggests they participate in the induction of fibrosis that represents the final stages of venous insufficiency.

\section{Eosinophils}

The primary role of eosinophils is in host defense against parasites by releasing cytotoxic cellular contents, including pro-inflammatory cytokines, chemokines, and lipid mediators (Kariyawasam and Robinson, 2006). In addition, eosinophils act as antigen-presenting cells and serve as inducers of tissue damage by releasing proteins and lipid mediators (Rothenberg and Hogan, 2006). Regarding the effects of aging on eosinophil numbers, a positive correlation between increased peripheral eosinophils and serum IL-6 levels was described after analyzing data from a cross-sectional analysis, including aged women from the Women's Health and Aging Study I (Leng et al., 2005). While the mechanisms underlying the origin of the association between the elevation of eosinophils and IL- 6 and described in this study need further investigation, these findings suggest a contribution of eosinophils to the age-related elevation in circulating IL-6 levels.

Eosinophils are involved in the pathogenesis of asthma, and their levels in the airway correlate with disease severity (Trivedi and Lloyd, 2007). While advanced age is associated with an increase in morbidity and mortality with asthma (Braman, 2003), no differences were found in the levels of eosinophils in the sputum of young and aged patients (Vignola et al., 2003) 
(Table 1). These results suggest that aging per se may not lead to increased severity of the disease, but rather, the duration of the disease may be a defining factor for the complication observed in aged patients (Vignola et al., 2003). In a recent study, eosinophil function was analyzed in young and aged asthma patients (Mathur et al., 2008). Relative to young patients, degranulation of eosinophil-derived neurotoxin (EDN) in response to IL-5 in vitro was decreased in aged asthma patients relative to young (Mathur et al., 2008). In addition, a tendency for reduced fMLP-stimulated EDN degranulation and production of $\mathrm{O}_{2}{ }^{-}$in response to PMA was found in the older group (Mathur et al., 2008). Other eosinophil functions, such as adhesion, chemotaxis towards eotaxin, as well as parameters of lung function and the percentage of sputum eosinophils were similar between young and aged patients (Mathur et al., 2008). These data confirm previous literature showing comparable airway eosinophilia in young and aged asthma patients (Vignola et al., 2003). While these findings do not represent age-related changes in the function of airway, they suggest that advanced age impairs eosinophil effector functions. Thus, differences in the response to allergens in the elderly due to age-related changes eosinophil function may help to explain the increased severity of asthma in aged subjects.

\section{Perspectives}

In the previous sections, we have addressed the contribution of cells of innate immune system to immunosenescence. While important in the context of aging, one must also consider that the aging phenotype is a consequence of the combined effects of dysfunctional immune, endocrine and nervous systems. In addition, the genetic makeup, in combination with environmental factors, such as oxidative damage, ultraviolet light and other types of radiation, individual lifestyles and geography all play a major role in determining the phenotype of the aged (Straub et al., 2001). The result of the interaction between all of the variables must be considered when the range of outcomes of the aged phenotype is observed. Of note, genetics is a main determinant of individual aging (Candore et al., 2006; Cournil and Kirkwood, 2001). In recent years, population studies have suggested that certain polymorphisms, including those involving innate immune responses, are linked to lifespan, responsiveness to stressors and pathology in the elderly (Franceschi et al., 2000; Salvioli et al., 2006). That is to assume that those genetic variants will be beneficial for some individuals to resist challenges and insults, such as infections, trauma or injury as they age.

While the genetic makeup can not be modified, interventions may help to reduce the aging phenotype and/or act as therapeutic agents (Nomellini et al., 2008b). In particular, we would like to briefly discuss the potential of those aimed at changing the components of the aged microenvironment towards a more youthful milieu. As a result of the aging process, dramatic changes occur in the endocrine system, particularly in the sex hormones (Gomez et al., 2008b). Thus, it is possible that the sex hormone environment may play a role in the effects of aging on the immune system, as well as in immune responses to injury and infection. When given at low doses, estrogen has a potent anti-inflammatory effect (Flake et al., 2006; Kovacs et al., 2002). In aged humans and rodents, estrogen administration prior to insult can accelerate dermal wound healing (Ashcroft et al., 1999), protects from cardiovascular disease (Moorthy et al., 2004), and improves systemic and cellular inflammatory responses to traumatic injury (Gomez et al., 2007b; Kovacs et al., 2004a; Kovacs et al., 2004b). However, as estrogen supplementation in postmenopausal women has been restricted due to increased cardiovascular disease and cancer (Kim and Morley, 2005; NAMS, 2007), precaution should be exerted in the design of therapeutic strategies involving this hormone.

In aged individuals without underlying disease, "inflamm-aging" (Franceschi et al., 2000), is characterized in part by circulating levels of IL-6 (Ershler, 1993; Ershler et al., 1994; Ershler et al., 1993). "Inflamm-aging" has been associated with mortality and disability among the 
elderly (Ferrucci et al., 1999). In an attempt to better define the role of this cytokine in the systemic inflammatory response in the aged, we challenged young and aged WT and IL-6 KO mice with LPS. Our results comparing LPS exposure in aged IL-6 KO mice with the same treatment in aged WT mice revealed improved survival (Gomez et al., 2006b), decreased acute phase response (Gomez et al., 2006b), and reduced hepatic injury (Gomez et al., 2008a). These observations suggest that blocking this cytokine's production and/or action on target cells may diminish aberrant innate immune responses and organ damage associated with hyperinflammatory responses in aged individuals. Determining the contribution of the diverse elements that define the aging phenotype to aberrant functioning of the innate immune system in the elderly will help to elucidate potential strategies for age-associated pathology, response to insults and extended longevity in the elderly.

\section{Acknowledgements}

This work was supported by the National Institutes of Health R01 AG018859 (EJK), NIH R01 AI056108 (DEF), F30 AG029724 (VN), American Federation for Aging Research (AFAR) (DEF), Illinois Excellence in Academic Medicine Award (EJK, DEF), and Ralph and Marian C. Falk Research Trust (EJK, DEF).

\section{References}

Agrawal A, Agrawal S, Tay J, Gupta S. Biology of dendritic cells in aging. J Clin Immunol 2008;28:1420. [PubMed: 17828583]

Albright, JF.; Albright, JW. Senescence of Natural/Innate Resistance to Infection: “Aging, Immunity, and Infection". Totowa, NY: Humana press, Inc; 2003. p. 61-135.

Albright JW, Albright JF. Age-associated impairment of murine natural killer activity. Proc Natl Acad Sci U S A 1983;80:6371-5. [PubMed: 6604919]

Allman D, Miller JP. The aging of early B-cell precursors. Immunol Rev 2005a;205:18-29. [PubMed: 15882342]

Allman D, Miller JP. B cell development and receptor diversity during aging. Curr Opin Immunol 2005b; 17:463-7. [PubMed: 16054808]

Arranz E, O’Mahony S, Barton JR, Ferguson A. Immunosenescence and mucosal immunity: significant effects of old age on secretory IgA concentrations and intraepithelial lymphocyte counts. Gut 1992;33:882-6. [PubMed: 1644326]

Ashcroft GS, Greenwell-Wild T, Horan MA, Wahl SM, Ferguson MW. Topical estrogen accelerates cutaneous wound healing in aged humans associated with an altered inflammatory response. Am J Pathol 1999;155:1137-46. [PubMed: 10514397]

Barbul A, Regan MC. Immune involvement in wound healing. Otolaryngol Clin North Am 1995;28:95568. [PubMed: 8559582]

Barreda DR, Hanington PC, Belosevic M. Regulation of myeloid development and function by colony stimulating factors. Dev Comp Immunol 2004;28:509-54. [PubMed: 15062647]

Bendelac A, Savage PB, Teyton L. The biology of NKT cells. Annu Rev Immunol 2007;25:297-336. [PubMed: 17150027]

Berzins SP, McNab FW, Jones CM, Smyth MJ, Godfrey DI. Long-term retention of mature NK1.1+ NKT cells in the thymus. J Immunol 2006;176:4059-65. [PubMed: 16547241]

Boehmer ED, Goral J, Faunce DE, Kovacs EJ. Age-dependent decrease in Toll-like receptor 4-mediated proinflammatory cytokine production and mitogen-activated protein kinase expression. J Leukoc Biol 2004;75:342-9. [PubMed: 14634059]

Boehmer ED, Meehan MJ, Cutro BT, Kovacs EJ. Aging negatively skews macrophage TLR2- and TLR4mediated pro-inflammatory responses without affecting the IL-2-stimulated pathway. Mech Ageing Dev 2005;126:1305-13. [PubMed: 16154177]

Borrego F, Alonso MC, Galiani MD, Carracedo J, Ramirez R, Ostos B, Pena J, Solana R. NK phenotypic markers and IL2 response in NK cells from elderly people. Exp Gerontol 1999;34:253-65. [PubMed: 10363791]

Braman SS. Asthma in the elderly. Clin Geriatr Med 2003;19:57-75. [PubMed: 12735115] 
Bruunsgaard H, Pedersen AN, Schroll M, Skinhoj P, Pedersen BK. Decreased natural killer cell activity is associated with atherosclerosis in elderly humans. Exp Gerontol 2001;37:127-36. [PubMed: 11738153]

Butcher SK, Chahal H, Nayak L, Sinclair A, Henriquez NV, Sapey E, O’Mahony D, Lord JM. Senescence in innate immune responses: reduced neutrophil phagocytic capacity and CD16 expression in elderly humans. J Leukoc Biol 2001;70:881-6. [PubMed: 11739550]

Candore G, Balistreri CR, Listi F, Grimaldi MP, Vasto S, Colonna-Romano G, Franceschi C, Lio D, Caselli G, Caruso C. Immunogenetics, gender, and longevity. Ann N Y Acad Sci 2006;1089:51637. [PubMed: 17261795]

Cao JJ, Kurimoto P, Boudignon B, Rosen C, Lima F, Halloran BP. Aging impairs IGF-I receptor activation and induces skeletal resistance to IGF-I. J Bone Miner Res 2007;22:1271-9. [PubMed: 17488198]

Cao JJ, Wronski TJ, Iwaniec U, Phleger L, Kurimoto P, Boudignon B, Halloran BP. Aging increases stromal/osteoblastic cell-induced osteoclastogenesis and alters the osteoclast precursor pool in the mouse. J Bone Miner Res 2005;20:1659-68. [PubMed: 16059637]

Celada A, Nathan C. Macrophage activation revisited. Immunol Today 1994;15:100-2. [PubMed: 7909663]

Chatta GS, Dale DC. Aging and haemopoiesis. Implications for treatment with haemopoietic growth factors. Drugs Aging 1996;9:37-47. [PubMed: 8818584]

Chaves MM, Costa DC, Pereira CC, Andrade TR, Horta BC, Nogueira-Machado JA. Role of inositol 1,4,5-triphosphate and p38 mitogen-activated protein kinase in reactive oxygen species generation by granulocytes in a cyclic AMP-dependent manner: an age-related phenomenon. Gerontology 2007;53:228-33. [PubMed: 17374957]

Chelvarajan RL, Collins SM, Van Willigen JM, Bondada S. The unresponsiveness of aged mice to polysaccharide antigens is a result of a defect in macrophage function. J Leukoc Biol 2005;77:50312. [PubMed: 15629885]

Chelvarajan RL, Liu Y, Popa D, Getchell ML, Getchell TV, Stromberg AJ, Bondada S. Molecular basis of age-associated cytokine dysregulation in LPS-stimulated macrophages. J Leukoc Biol 2006;79:1314-27. [PubMed: 16603589]

Chilvers ER, Cadwallader KA, Reed BJ, White JF, Condliffe AM. The function and fate of neutrophils at the inflamed site: prospects for therapeutic intervention. J R Coll Physicians Lond 2000;34:6874. [PubMed: 10717886]

Clark JA, Peterson TC. Cytokine production and aging: overproduction of IL-8 in elderly males in response to lipopolysaccharide. Mech Ageing Dev 1994;77:127-39. [PubMed: 7745991]

Corsini E, Di Paola R, Viviani B, Genovese T, Mazzon E, Lucchi L, Marinovich M, Galli CL, Cuzzocrea S. Increased carrageenan-induced acute lung inflammation in old rats. Immunology 2005;115:25361. [PubMed: 15885132]

Cournil A, Kirkwood TB. If you would live long, choose your parents well. Trends Genet 2001;17:2335. [PubMed: 11335017]

Dace DS, Apte RS. Effect of senescence on macrophage polarization and angiogenesis. Rejuvenation Res 2008;11:177-85. [PubMed: 18279031]

Danon D, Kowatch MA, Roth GS. Promotion of wound repair in old mice by local injection of macrophages. Proc Natl Acad Sci U S A 1989;86:2018-20. [PubMed: 2928316]

Davis CF, Moore FD Jr, Rodrick ML, Fearon DT, Mannick JA. Neutrophil activation after burn injury: contributions of the classic complement pathway and of endotoxin. Surgery 1987;102:477-84. [PubMed: 3307005]

De La Fuente M. Changes in the macrophage function with aging. Comp Biochem Physiol A 1985;81:935-8. [PubMed: 2863082]

DelaRosa O, Tarazona R, Casado JG, Alonso C, Ostos B, Pena J, Solana R. Valpha24+ NKT cells are decreased in elderly humans. Exp Gerontol 2002;37:213-7. [PubMed: 11772506]

Delpedro AD, Barjavel MJ, Mamdouh Z, Faure S, Bakouche O. Signal transduction in LPS-activated aged and young monocytes. J Interferon Cytokine Res 1998;18:429-37. [PubMed: 9660251] 
Di Lorenzo G, Balistreri CR, Candore G, Cigna D, Colombo A, Romano GC, Colucci AT, Gervasi F, Listi F, Potestio M, Caruso C. Granulocyte and natural killer activity in the elderly. Mech Ageing Dev 1999;108:25-38. [PubMed: 10366037]

Di Nardo A, Vitiello A, Gallo RL. Cutting edge: mast cell antimicrobial activity is mediated by expression of cathelicidin antimicrobial peptide. J Immunol 2003;170:2274-8. [PubMed: 12594247]

Ding A, Hwang S, Schwab R. Effect of aging on murine macrophages. Diminished response to IFNgamma for enhanced oxidative metabolism. J Immunol 1994;153:2146-52. [PubMed: 7519641]

Dubey DP, Husain Z, Levitan E, Zurakowski D, Mirza N, Younes S, Coronell C, Yunis D, Yunis EJ. The MHC influences NK and NKT cell functions associated with immune abnormalities and lifespan. Mech Ageing Dev 2000;113:117-34. [PubMed: 10708259]

Effros RB. Genetic alterations in the ageing immune system: impact on infection and cancer. Mech Ageing Dev 2003;124:71-7. [PubMed: 12618008]

Elder AC, Gelein R, Finkelstein JN, Cox C, Oberdorster G. Pulmonary inflammatory response to inhaled ultrafine particles is modified by age, ozone exposure, and bacterial toxin. Inhal Toxicol 2000;12 (Suppl 4):227-46. [PubMed: 12881894]

Ershler WB. Interleukin-6: a cytokine for gerontologists. J Am Geriatr Soc 1993;41:176-81. [PubMed: 8426042]

Ershler WB, Sun WH, Binkley N. The role of interleukin-6 in certain age-related diseases. Drugs Aging 1994;5:358-65. [PubMed: 7833589]

Ershler WB, Sun WH, Binkley N, Gravenstein S, Volk MJ, Kamoske G, Klopp RG, Roecker EB, Daynes RA, Weindruch R. Interleukin-6 and aging: blood levels and mononuclear cell production increase with advancing age and in vitro production is modifiable by dietary restriction. Lymphokine Cytokine Res 1993;12:225-30. [PubMed: 8218595]

Fassbender K, Walter S, Kuhl S, Landmann R, Ishii K, Bertsch T, Stalder AK, Muehlhauser F, Liu Y, Ulmer AJ, Rivest S, Lentschat A, Gulbins E, Jucker M, Staufenbiel M, Brechtel K, Walter J, Multhaup G, Penke B, Adachi Y, Hartmann T, Beyreuther K. The LPS receptor (CD14) links innate immunity with Alzheimer's disease. Faseb J 2004;18:203-5. [PubMed: 14597556]

Faunce, DE.; Palmer, JL. Chapter 3.5: The effects of age on CD1d-restricted NKT cells and their contribution to the age-associated decline of T cell immunity. In: Fulop, T.; Franceschi, C.; Hirokawa, K.; Pawelec, G., editors. Immunosenescence Handbook. New York, NY: Springer Press; 2008.

Faunce DE, Palmer JL, Paskowicz KK, Witte PL, Kovacs EJ. CD1d-restricted NKT cells contribute to the age-associated decline of T cell immunity. J Immunol 2005;175:3102-9. [PubMed: 16116199]

Fernandes G, Gupta S. Natural killing and antibody-dependent cytotoxicity by lymphocyte subpopulations in young and aging humans. J Clin Immunol 1981;1:141-8. [PubMed: 6977553]

Ferrucci L, Harris TB, Guralnik JM, Tracy RP, Corti MC, Cohen HJ, Penninx B, Pahor M, Wallace R, Havlik RJ. Serum IL-6 level and the development of disability in older persons. J Am Geriatr Soc 1999;47:639-46. [PubMed: 10366160]

Fietta A, Merlini C, De Bernardi PM, Gandola L, Piccioni PD, Grassi C. Non specific immunity in aged healthy subjects and in patients with chronic bronchitis. Aging (Milano) 1993;5:357-61. [PubMed: 8123696]

Finlay-Jones JJ, Davies KV, Sturm LP, Kenny PA, Hart PH. Inflammatory processes in a murine model of intra-abdominal abscess formation. J Leukoc Biol 1999;66:583-7. [PubMed: 10534113]

Flake NM, Hermanstyne TO, Gold MS. Testosterone and estrogen have opposing actions on inflammation-induced plasma extravasation in the rat temporomandibular joint. Am J Physiol Regul Integr Comp Physiol 2006;291:R343-8. [PubMed: 16469833]

Fortin CF, Larbi A, Dupuis G, Lesur O, Fulop T Jr. GM-CSF activates the Jak/STAT pathway to rescue polymorphonuclear neutrophils from spontaneous apoptosis in young but not elderly individuals. Biogerontology 2007a;8:173-87. [PubMed: 17086367]

Fortin CF, Larbi A, Lesur O, Douziech N, Fulop T Jr. Impairment of SHP-1 down-regulation in the lipid rafts of human neutrophils under GM-CSF stimulation contributes to their age-related, altered functions. J Leukoc Biol 2006;79:1061-72. [PubMed: 16501054]

Fortin CF, Lesur O, Fulop T Jr. Effects of aging on triggering receptor expressed on myeloid cells (TREM)-1-induced PMN functions. FEBS Lett 2007b;581:1173-8. [PubMed: 17336301] 
Franceschi C, Bonafe M, Valensin S, Olivieri F, De Luca M, Ottaviani E, De Benedictis G. Inflammaging. An evolutionary perspective on immunosenescence. Ann N Y Acad Sci 2000;908:244-54. [PubMed: 10911963]

Franceschi C, Monti D, Barbieri D, Salvioli S, Grassilli E, Capri M, Troiano L, Guido M, Bonafe M, Tropea F, Salomoni P, Benatti F, Bellesia E, Macchioni S, Anderlini R, Sansoni P, Mariotti S, Wratten ML, Tetta C, Cossarizza A. Successful immunosenescence and the remodelling of immune responses with ageing. Nephrol Dial Transplant 1996;11(Suppl 9):18-25. [PubMed: 9050030]

Franceschi C, Monti D, Sansoni P, Cossarizza A. The immunology of exceptional individuals: the lesson of centenarians. Immunol Today 1995;16:12-6. [PubMed: 7880382]

Fulop T Jr, Foris G, Worum I, Paragh G, Leovey A. Age related variations of some polymorphonuclear leukocyte functions. Mech Ageing Dev 1985;29:1-8. [PubMed: 3845309]

Fulop T Jr, Fouquet C, Allaire P, Perrin N, Lacombe G, Stankova J, Rola-Pleszczynski M, Gagne D, Wagner JR, Khalil A, Dupuis G. Changes in apoptosis of human polymorphonuclear granulocytes with aging. Mech Ageing Dev 1997a;96:15-34. [PubMed: 9223108]

Fulop T Jr, Larbi A, Linteau A, Desgeorges S, Douziech N. The role of Mcl-1 and Bax expression alteration in the decreased rescue of human neutrophils from apoptosis by GM-CSF with aging. Ann N Y Acad Sci 2002;973:305-8. [PubMed: 12485884]

Fulop T Jr, Varga Z, Jacob MP, Robert L. Effect of lithium on superoxide production and intracellular free calcium mobilization in elastin peptide (kappa-elastin) and FMLP stimulated human PMNS. Effect of age. Life Sci 1997b;60:PL 325-32.

Fulop T, Larbi A, Douziech N, Fortin C, Guerard KP, Lesur O, Khalil A, Dupuis G. Signal transduction and functional changes in neutrophils with aging. Aging Cell 2004;3:217-26. [PubMed: 15268755]

Furuta T, Kikuchi T, Iwakura Y, Watanabe N. Protective roles of mast cells and mast cell-derived TNF in murine malaria. J Immunol 2006;177:3294-302. [PubMed: 16920970]

Galli SJ, Kalesnikoff J, Grimbaldeston MA, Piliponsky AM, Williams CM, Tsai M. Mast cells as "tunable" effector and immunoregulatory cells: recent advances. Annu Rev Immunol 2005;23:749_ 86. [PubMed: 15771585]

Gomez CR, Acuna-Castillo C, Nishimura S, Perez V, Escobar A, Salazar-Onfray F, Sabaj V, Torres C, Walter R, Sierra F. Serum from aged F344 rats conditions the activation of young macrophages. Mech Ageing Dev 2006a;127:257-63. [PubMed: 16343598]

Gomez CR, Boehmer ED, Kovacs EJ. The aging innate immune system. Curr Opin Immunol 2005;17:457-462. [PubMed: 16084711]

Gomez CR, Goral J, Ramirez L, Kopf M, Kovacs EJ. Aberrant acute-phase response in aged interleukin-6 knockout mice. Shock 2006b;25:581-5. [PubMed: 16721265]

Gomez CR, Hirano S, Cutro BT, Birjandi S, Baila H, Nomellini V, Kovacs EJ. Advanced age exacerbates the pulmonary inflammatory response after lipopolysaccharide exposure. Crit Care Med 2007a; 35:246-51. [PubMed: 17133178]

Gomez CR, Nomellini V, Baila H, Oshima K, Kovacs EJ. Comparison of the effects of aging and IL-6 on the hepatic inflammatory response in two models of systemic injury: scald injury versus i.p. LPS administration. Shock. 2008ain press

Gomez, CR.; Nomellini, V.; Kovacs, EJ. Chapter 4.5: Sex hormones and immunosenescence. In: Fulop, T.; Franceschi, C.; Hirokawa, K.; Pawelec, G., editors. Immunosenescence Handbook. New York, NY: Springer Press; 2008b.

Gomez CR, Plackett TP, Kovacs EJ. Aging and estrogen: modulation of inflammatory responses after injury. Exp Gerontol 2007b;42:451-6. [PubMed: 17204391]

Gosain A, DiPietro LA. Aging and wound healing. World J Surg 2004;28:321-6. [PubMed: 14961191]

Hart PH, Grimbaldeston MA, Hosszu EK, Swift GJ, Noonan FP, Finlay-Jones JJ. Age-related changes in dermal mast cell prevalence in BALB/c mice: functional importance and correlation with dermal mast cell expression of Kit. Immunology 1999;98:352-6. [PubMed: 10583593]

Herrero C, Sebastian C, Marques L, Comalada M, Xaus J, Valledor AF, Lloberas J, Celada A. Immunosenescence of macrophages: reduced MHC class II gene expression. Exp Gerontol 2002;37:389-94. [PubMed: 11772525] 
Hilkens CM, Snijders A, Snijdewint FG, Wierenga EA, Kapsenberg ML. Modulation of T-cell cytokine secretion by accessory cell-derived products. Eur Respir J Suppl 1996;22:90s-94s. [PubMed: 8871051]

Hilmer SN, Cogger VC, Le Couteur DG. Basal activity of Kupffer cells increases with old age. J Gerontol A Biol Sci Med Sci 2007;62:973-8. [PubMed: 17895435]

Ingalls RR, Heine H, Lien E, Yoshimura A, Golenbock D. Lipopolysaccharide recognition, CD14, and lipopolysaccharide receptors. Infect Dis Clin North Am 1999;13:341-53. vii. [PubMed: 10340170]

Ishimoto Y, Tomiyama-Miyaji C, Watanabe H, Yokoyama H, Ebe K, Tsubata S, Aoyagi Y, Abo T. Agedependent variation in the proportion and number of intestinal lymphocyte subsets, especially natural killer T cells, double-positive CD4+ CD8+ cells and B220+ T cells, in mice. Immunology 2004;113:371-7. [PubMed: 15500624]

Ito Y, Kajkenova O, Feuers RJ, Udupa KB, Desai VG, Epstein J, Hart RW, Lipschitz DA. Impaired glutathione peroxidase activity accounts for the age-related accumulation of hydrogen peroxide in activated human neutrophils. J Gerontol A Biol Sci Med Sci 1998;53:M169-75. [PubMed: 9597047]

Johansen JS, Pedersen AN, Schroll M, Jorgensen T, Pedersen BK, Bruunsgaard H. High serum YKL-40 level in a cohort of octogenarians is associated with increased risk of all-cause mortality. Clin Exp Immunol 2008;151:260-6. [PubMed: 18070151]

Joyce S. CD1d and natural T cells: how their properties jump-start the immune system. Cell Mol Life Sci 2001;58:442-69. [PubMed: 11315191]

Kariyawasam HH, Robinson DS. The eosinophil: the cell and its weapons, the cytokines, its locations. Semin Respir Crit Care Med 2006;27:117-27. [PubMed: 16612762]

Kasper JD, Shapiro S, Guralnik JM, Bandeen-Roche KJ, Fried LP. Designing a community study of moderately to severely disabled older women: the Women's Health and Aging Study. Ann Epidemiol 1999;9:498-507. [PubMed: 10549883]

Katz JM, Plowden J, Renshaw-Hoelscher M, Lu X, Tumpey TM, Sambhara S. Immunity to influenza: the challenges of protecting an aging population. Immunol Res 2004;29:113-24. [PubMed: 15181275]

Kelly J, Ali Khan A, Yin J, Ferguson TA, Apte RS. Senescence regulates macrophage activation and angiogenic fate at sites of tissue injury in mice. J Clin Invest 2007;117:3421-6. [PubMed: 17975672]

Kim MJ, Morley JE. The hormonal fountains of youth: myth or reality? J Endocrinol Invest 2005;28:514. [PubMed: 16760618]

Kovacs EJ, Duffner LA, Plackett TP. Immunosuppression after injury in aged mice is associated with a TH1-TH2 shift, which can be restored by estrogen treatment. Mech Ageing Dev 2004a;125:121-3. [PubMed: 15037015]

Kovacs EJ, Messingham KA, Gregory MS. Estrogen regulation of immune responses after injury. Mol Cell Endocrinol 2002;193:129-35. [PubMed: 12161012]

Kovacs EJ, Plackett TP, Witte PL. Estrogen replacement, aging, and cell-mediated immunity after injury. J Leukoc Biol 2004b;76:36-41. [PubMed: 14761938]

Krabbe KS, Pedersen M, Bruunsgaard H. Inflammatory mediators in the elderly. Exp Gerontol 2004;39:687-99. [PubMed: 15130663]

Larbi A, Douziech N, Fortin C, Linteau A, Dupuis G, Fulop T Jr. The role of the MAPK pathway alterations in GM-CSF modulated human neutrophil apoptosis with aging. Immun Ageing 2005;2:6. [PubMed: 15743527]

Larbi A, Franceschi C, Mazzatti D, Solana R, Wikby A, Pawelec G. Aging of the immune system as a prognostic factor for human longevity. Physiology (Bethesda) 2008;23:64-74. [PubMed: 18400689]

Lehrer RI, Ganz T, Selsted ME, Babior BM, Curnutte JT. Neutrophils and host defense. Ann Intern Med 1988;109:127-42. [PubMed: 3289431]

Leng S, Xue QL, Huang Y, Semba R, Chaves P, Bandeen-Roche K, Fried L, Walston J. Total and differential white blood cell counts and their associations with circulating interleukin-6 levels in community-dwelling older women. J Gerontol A Biol Sci Med Sci 2005;60:195-9. [PubMed: 15814862]

Linton PJ, Dorshkind K. Age-related changes in lymphocyte development and function. Nat Immunol 2004;5:133-9. [PubMed: 14749784] 
Lipschitz DA, Udupa KB, Indelicato SR, Das M. Effect of age on second messenger generation in neutrophils. Blood 1991;78:1347-54. [PubMed: 1652310]

Long JM, Kalehua AN, Muth NJ, Calhoun ME, Jucker M, Hengemihle JM, Ingram DK, Mouton PR. Stereological analysis of astrocyte and microglia in aging mouse hippocampus. Neurobiol Aging 1998;19:497-503. [PubMed: 9880052]

Lord JM, Butcher S, Killampali V, Lascelles D, Salmon M. Neutrophil ageing and immunesenescence. Mech Ageing Dev 2001;122:1521-35. [PubMed: 11511394]

Mantovani A, Sozzani S, Locati M, Allavena P, Sica A. Macrophage polarization: tumor-associated macrophages as a paradigm for polarized M2 mononuclear phagocytes. Trends Immunol 2002;23:549-55. [PubMed: 12401408]

Mariani E, Pulsatelli L, Meneghetti A, Dolzani P, Mazzetti I, Neri S, Ravaglia G, Forti P, Facchini A. Different IL-8 production by T and NK lymphocytes in elderly subjects. Mech Ageing Dev 2001;122:1383-95. [PubMed: 11470128]

Mariani E, Pulsatelli L, Neri S, Dolzani P, Meneghetti A, Silvestri T, Ravaglia G, Forti P, Cattini L, Facchini A. RANTES and MIP-1alpha production by T lymphocytes, monocytes and NK cells from nonagenarian subjects. Exp Gerontol 2002;37:219-26. [PubMed: 11772507]

Martin GS, Mannino DM, Moss M. The effect of age on the development and outcome of adult sepsis. Crit Care Med 2006;34:15-21. [PubMed: 16374151]

Martinez FO, Sica A, Mantovani A, Locati M. Macrophage activation and polarization. Front Biosci 2008;13:453-61. [PubMed: 17981560]

Mathur SK, Schwantes EA, Jarjour NN, Busse WW. Age-related changes in eosinophil function in human subjects. Chest 2008;133:412-9. [PubMed: 18252914]

McDermott JR, Bartram RE, Knight PA, Miller HR, Garrod DR, Grencis RK. Mast cells disrupt epithelial barrier function during enteric nematode infection. Proc Natl Acad Sci U S A 2003;100:7761-6. [PubMed: 12796512]

McLachlan JB, Hart JP, Pizzo SV, Shelburne CP, Staats HF, Gunn MD, Abraham SN. Mast cell-derived tumor necrosis factor induces hypertrophy of draining lymph nodes during infection. Nat Immunol 2003;4:1199-205. [PubMed: 14595438]

Metz M, Maurer M. Mast cells--key effector cells in immune responses. Trends Immunol 2007;28:23441. [PubMed: 17400512]

Miller AP, Xing D, Feng W, Fintel M, Chen YF, Oparil S. Aged rats lose vasoprotective and antiinflammatory actions of estrogen in injured arteries. Menopause 2007;14:251-60. [PubMed: 17194962]

Mocchegiani E, Giacconi R, Cipriano C, Gasparini N, Bernardini G, Malavolta M, Menegazzi M, Cavalieri E, Muzzioli M, Ciampa AR, Suzuki H. The variations during the circadian cycle of liver CD1d-unrestricted NK1.1+TCR gamma/delta+ cells lead to successful ageing. Role of metallothionein/IL-6/gp130/PARP-1 interplay in very old mice. Exp Gerontol 2004;39:775-88. [PubMed: 15130672]

Mocchegiani E, Malavolta M. NK and NKT cell functions in immunosenescence. Aging Cell 2004;3:177-84. [PubMed: 15268751]

Mocchegiani E, Muzzioli M, Giacconi R, Cipriano C, Gasparini N, Franceschi C, Gaetti R, Cavalieri E, Suzuki H. Metallothioneins/PARP-1/IL-6 interplay on natural killer cell activity in elderly: parallelism with nonagenarians and old infected humans. Effect of zinc supply. Mech Ageing Dev 2003;124:459-68. [PubMed: 12714254]

Montagna W, Carlisle K. Structural changes in ageing skin. Br J Dermatol 1990;122(Suppl 35):61-70. [PubMed: 2186788]

Moorthy K, Yadav UC, Mantha AK, Cowsik SM, Sharma D, Basir SF, Baquer NZ. Estradiol and progesterone treatments change the lipid profile in naturally menopausal rats from different age groups. Biogerontology 2004;5:411-9. [PubMed: 15609105]

Mouton PR, Long JM, Lei DL, Howard V, Jucker M, Calhoun ME, Ingram DK. Age and gender effects on microglia and astrocyte numbers in brains of mice. Brain Res 2002;956:30-5. [PubMed: 12426043]

Mullick AE, Tobias PS, Curtiss LK. Toll-like receptors and atherosclerosis: key contributors in disease and health? Immunol Res 2006;34:193-209. [PubMed: 16891671] 
Murasko DM, Jiang J. Response of aged mice to primary virus infections. Immunol Rev 2005;205:28596. [PubMed: 15882361]

Mysliwska J, Bryl E, Bigda J, Kmiec Z, Foerster J, Mysliwski A. Activity of NK in elderly people. Acta Haematol Pol 1992a;23:245-51. [PubMed: 1293905]

Mysliwska J, Mysliwski A, Romanowski P, Bigda J, Sosnowska D, Foerster J. Monocytes are responsible for depressed natural killer (NK) activity in both young and elderly low NK responders. Gerontology 1992b;38:41-9. [PubMed: 1535328]

Nadziejko C, Fang K, Narciso S, Zhong M, Su WC, Gordon T, Nadas A, Chen LC. Effect of particulate and gaseous pollutants on spontaneous arrhythmias in aged rats. Inhal Toxicol 2004;16:373-80. [PubMed: 15204753]

Nagel JE, Pyle RS, Chrest FJ, Adler WH. Oxidative metabolism and bactericidal capacity of polymorphonuclear leukocytes from normal young and aged adults. J Gerontol 1982;37:529-34. [PubMed: 6284832]

NAMS. Estrogen and progestogen use in peri- and postmenopausal women: March 2007 position statement of The North American Menopause Society. Menopause 2007;14:168-82. [PubMed: 17259911]

Nguyen M, Pace AJ, Koller BH. Age-induced reprogramming of mast cell degranulation. J Immunol 2005;175:5701-7. [PubMed: 16237060]

Nigrovic PA, Binstadt BA, Monach PA, Johnsen A, Gurish M, Iwakura Y, Benoist C, Mathis D, Lee DM. Mast cells contribute to initiation of autoantibody-mediated arthritis via IL-1. Proc Natl Acad Sci U S A 2007;104:2325-30. [PubMed: 17277081]

Nomellini V, Faunce DE, Gomez CR, Kovacs EJ. An age-associated increase in pulmonary inflammation after burn injury is abrogated by CXCR2 inhibition. J Leuk Biol. 2008ain press

Nomellini, V.; Gomez, C.; Kovacs, EJ. Impairment of Innate Immunity: Hereditary and Age Related Alterations. In: Herwald, H.; Egesten, A.; Schmidt, A., editors. Contributions to Microbiology: Innate Immunity. Karger AG; Basel, Switzerland: 2008b. In press

Ogata K, Yokose N, Tamura H, An E, Nakamura K, Dan K, Nomura T. Natural killer cells in the late decades of human life. Clin Immunol Immunopathol 1997;84:269-75. [PubMed: 9281385]

Ogawa T, Kitagawa M, Hirokawa K. Age-related changes of human bone marrow: a histometric estimation of proliferative cells, apoptotic cells, T cells, B cells and macrophages. Mech Ageing Dev 2000;117:57-68. [PubMed: 10958923]

Pascual G, Mendieta C, Garcia-Honduvilla N, Corrales C, Bellon JM, Bujan J. TGF-beta1 upregulation in the aging varicose vein. J Vasc Res 2007;44:192-201. [PubMed: 17337905]

Pawelec G, Akbar A, Caruso C, Solana R, Grubeck-Loebenstein B, Wikby A. Human immunosenescence: is it infectious? Immunol Rev 2005;205:257-68. [PubMed: 15882359]

Peralbo E, Alonso C, Solana R. Invariant NKT and NKT-like lymphocytes: two different T cell subsets that are differentially affected by ageing. Exp Gerontol 2007;42:703-8. [PubMed: 17604928]

Peralbo E, DelaRosa O, Gayoso I, Pita ML, Tarazona R, Solana R. Decreased frequency and proliferative response of invariant Valpha24Vbeta11 natural killer T (iNKT) cells in healthy elderly. Biogerontology 2006;7:483-92. [PubMed: 16953330]

Piazzolla G, Tortorella C, Serrone M, Jirillo E, Antonaci S. Modulation of cytoskeleton assembly capacity and oxidative response in aged neutrophils. Immunopharmacol Immunotoxicol 1998;20:251-66. [PubMed: 9653671]

Plackett TP, Boehmer ED, Faunce DE, Kovacs EJ. Aging and innate immune cells. J Leukoc Biol 2004;76:291-9. [PubMed: 15039467]

Plowden J, Renshaw-Hoelscher M, Engleman C, Katz J, Sambhara S. Innate immunity in aging: impact on macrophage function. Aging Cell 2004a;3:161-7. [PubMed: 15268749]

Plowden J, Renshaw-Hoelscher M, Gangappa S, Engleman C, Katz JM, Sambhara S. Impaired antigeninduced CD8+ T cell clonal expansion in aging is due to defects in antigen presenting cell function. Cell Immunol 2004b;229:86-92. [PubMed: 15474523]

Poynter ME, Mu HH, Chen XP, Daynes RA. Activation of NK1.1+ T cells in vitro and their possible role in age-associated changes in inducible IL-4 production. Cell Immunol 1997;179:22-9. [PubMed: 9259768] 
Prelog M. Aging of the immune system: a risk factor for autoimmunity? Autoimmun Rev 2006;5:1369. [PubMed: 16431345]

Radsak MP, Salih HR, Rammensee HG, Schild H. Triggering receptor expressed on myeloid cells-1 in neutrophil inflammatory responses: differential regulation of activation and survival. J Immunol 2004;172:4956-63. [PubMed: 15067076]

Rao KM. Age-related decline in ligand-induced actin polymerization in human leukocytes and platelets. J Gerontol 1986;41:561-6. [PubMed: 3745810]

Ravaglia G, Forti P, Maioli F, Bastagli L, Facchini A, Mariani E, Savarino L, Sassi S, Cucinotta D, Lenaz G. Effect of micronutrient status on natural killer cell immune function in healthy free-living subjects aged >/=90 y. Am J Clin Nutr 2000;71:590-8. [PubMed: 10648276]

Renshaw M, Rockwell J, Engleman C, Gewirtz A, Katz J, Sambhara S. Cutting edge: impaired Toll-like receptor expression and function in aging. J Immunol 2002;169:4697-701. [PubMed: 12391175]

Riley RL, Blomberg BB, Frasca D. B cells, E2A, and aging. Immunol Rev 2005;205:30-47. [PubMed: 15882343]

Rothenberg ME, Hogan SP. The eosinophil. Annu Rev Immunol 2006;24:147-74. [PubMed: 16551246]

Saito H, Patterson C, Hu Z, Runge MS, Tipnis U, Sinha M, Papaconstantinou J. Expression and selfregulatory function of cardiac interleukin-6 during endotoxemia. Am J Physiol Heart Circ Physiol 2000;279:H2241-8. [PubMed: 11045959]

Saito H, Sherwood ER, Varma TK, Evers BM. Effects of aging on mortality, hypothermia, and cytokine induction in mice with endotoxemia or sepsis. Mech Ageing Dev 2003;124:1047-58. [PubMed: 14659593]

Salvioli S, Capri M, Valensin S, Tieri P, Monti D, Ottaviani E, Franceschi C. Inflamm-aging, cytokines and aging: state of the art, new hypotheses on the role of mitochondria and new perspectives from systems biology. Curr Pharm Des 2006;12:3161-71. [PubMed: 16918441]

Sansoni P, Cossarizza A, Brianti V, Fagnoni F, Snelli G, Monti D, Marcato A, Passeri G, Ortolani C, Forti E, et al. Lymphocyte subsets and natural killer cell activity in healthy old people and centenarians. Blood 1993;82:2767-73. [PubMed: 8219229]

Savill JS, Wyllie AH, Henson JE, Walport MJ, Henson PM, Haslett C. Macrophage phagocytosis of aging neutrophils in inflammation. Programmed cell death in the neutrophil leads to its recognition by macrophages. J Clin Invest 1989;83:865-75. [PubMed: 2921324]

Sebastian C, Espia M, Serra M, Celada A, Lloberas J. MacrophAging: a cellular and molecular review. Immunobiology 2005;210:121-6. [PubMed: 16164018]

Sibille Y, Marchandise FX. Pulmonary immune cells in health and disease: polymorphonuclear neutrophils. Eur Respir J 1993;6:1529-43. [PubMed: 8112448]

Sibille Y, Reynolds HY. Macrophages and polymorphonuclear neutrophils in lung defense and injury. Am Rev Respir Dis 1990;141:471-501. [PubMed: 2405761]

Solana R, Mariani E. NK and NK/T cells in human senescence. Vaccine 2000;18:1613-20. [PubMed: 10689137]

Solana R, Pawelec G, Tarazona R. Aging and innate immunity. Immunity 2006;24:491-4. [PubMed: 16713963]

Spencer NF, Norton SD, Harrison LL, Li GZ, Daynes RA. Dysregulation of IL-10 production with aging: possible linkage to the age-associated decline in DHEA and its sulfated derivative. Exp Gerontol 1996;31:393-408. [PubMed: 9415122]

Stout RD, Jiang C, Matta B, Tietzel I, Watkins SK, Suttles J. Macrophages sequentially change their functional phenotype in response to changes in microenvironmental influences. J Immunol 2005;175:342-9. [PubMed: 15972667]

Stout RD, Suttles J. Immunosenescence and macrophage functional plasticity: dysregulation of macrophage function by age-associated microenvironmental changes. Immunol Rev 2005;205:6071. [PubMed: 15882345]

Straub RH, Cutolo M, Zietz B, Scholmerich J. The process of aging changes the interplay of the immune, endocrine and nervous systems. Mech Ageing Dev 2001;122:1591-611. [PubMed: 11511399]

Sunil VR, Laumbach RJ, Patel KJ, Turpin BJ, Lim HJ, Kipen HM, Laskin JD, Laskin DL. Pulmonary effects of inhaled limonene ozone reaction products in elderly rats. Toxicol Appl Pharmacol 2007;222:211-20. [PubMed: 17610924] 
Swift ME, Burns AL, Gray KL, DiPietro LA. Age-related alterations in the inflammatory response to dermal injury. J Invest Dermatol 2001;117:1027-35. [PubMed: 11710909]

Tateda K, Matsumoto T, Miyazaki S, Yamaguchi K. Lipopolysaccharide-induced lethality and cytokine production in aged mice. Infect Immun 1996;64:769-74. [PubMed: 8641780]

Tchkonia T, Pirtskhalava T, Thomou T, Cartwright MJ, Wise B, Karagiannides I, Shpilman A, Lash TL, Becherer JD, Kirkland JL. Increased TNF $\{$ alpha $\}$ and CCAAT/enhancer-binding protein homologous protein with aging predispose preadipocytes to resist adipogenesis. Am J Physiol Endocrinol Metab 2007;293:E1810-9. [PubMed: 17911345]

Teitelbaum SL, Ross FP. Genetic regulation of osteoclast development and function. Nat Rev Genet 2003;4:638-49. [PubMed: 12897775]

Tortorella C, Piazzolla G, Napoli N, Antonaci S. Neutrophil apoptotic cell death: does it contribute to the increased infectious risk in aging? Microbios 2001;106:129-36. [PubMed: 11506063]

Tortorella C, Simone O, Piazzolla G, Stella I, Antonaci S. Age-related impairment of GM-CSF-induced signalling in neutrophils: role of SHP-1 and SOCS proteins. Ageing Res Rev 2007;6:81-93. [PubMed: 17142110]

Tortorella C, Simone O, Piazzolla G, Stella I, Cappiello V, Antonaci S. Role of phosphoinositide 3-kinase and extracellular signal-regulated kinase pathways in granulocyte macrophage-colony-stimulating factor failure to delay fas-induced neutrophil apoptosis in elderly humans. J Gerontol A Biol Sci Med Sci 2006;61:1111-8. [PubMed: 17167151]

Trivedi SG, Lloyd CM. Eosinophils in the pathogenesis of allergic airways disease. Cell Mol Life Sci 2007;64:1269-89. [PubMed: 17364144]

Tsukahara A, Seki S, Iiai T, Moroda T, Watanabe H, Suzuki S, Tada T, Hiraide H, Hatakeyama K, Abo T. Mouse liver T cells: their change with aging and in comparison with peripheral T cells. Hepatology 1997;26:301-9. [PubMed: 9252138]

Underhill DM, Ozinsky A. Phagocytosis of microbes: complexity in action. Annu Rev Immunol 2002;20:825-52. [PubMed: 11861619]

van Duin D, Mohanty S, Thomas V, Ginter S, Montgomery RR, Fikrig E, Allore HG, Medzhitov R, Shaw AC. Age-associated defect in human TLR-1/2 function. J Immunol 2007;178:970-5. [PubMed: 17202359]

Vega VL, De Cabo R, De Maio A. Age and caloric restriction diets are confounding factors that modify the response to lipopolysaccharide by peritoneal macrophages in C57BL/6 mice. Shock 2004;22:248-53. [PubMed: 15316395]

Videla LA, Tapia G, Fernandez V. Influence of aging on Kupffer cell respiratory activity in relation to particle phagocytosis and oxidative stress parameters in mouse liver. Redox Rep 2001;6:155-9. [PubMed: 11523590]

Vignola AM, Bonanno A, Profita M, Riccobono L, Scichilone N, Spatafora M, Bousquet J, Bonsignore G, Bellia V. Effect of age and asthma duration upon elastase and alpha1-antitrypsin levels in adult asthmatics. Eur Respir J 2003;22:795-801. [PubMed: 14621087]

Vomel T, Platt D, Schnorr B. Phagocytosis activity of the isolated perfused liver in rats of different ages. Biochemical and ultrastructural examination after perfusion with colloidal ink. Fortschr Med 1981;99:1511-5. [PubMed: 7297990]

Weng NP. Aging of the immune system: how much can the adaptive immune system adapt? Immunity 2006;24:495-9. [PubMed: 16713964]

Wenisch C, Patruta S, Daxbock F, Krause R, Horl W. Effect of age on human neutrophil function. J Leukoc Biol 2000;67:40-5. [PubMed: 10647996]

Wu D, Hayek MG, Meydani S. Vitamin E and macrophage cyclooxygenase regulation in the aged. J Nutr 2001;131:382S-8S. [PubMed: 11160566]

Wu D, Marko M, Claycombe K, Paulson KE, Meydani SN. Ceramide-induced and age-associated increase in macrophage COX-2 expression is mediated through up-regulation of NF-kappa B activity. J Biol Chem 2003;278:10983-92. [PubMed: 12529332]

Wu D, Ren Z, Pae M, Guo W, Cui X, Merrill AH, Meydani SN. Aging up-regulates expression of inflammatory mediators in mouse adipose tissue. J Immunol 2007;179:4829-39. [PubMed: 17878382] 
Yagi T, Sato A, Hayakawa H, Ide K. Failure of aged rats to accumulate eosinophils in allergic inflammation of the airway. J Allergy Clin Immunol 1997;99:38-47. [PubMed: 9003209]

Yamano T, DeCicco LA, Rikans LE. Attenuation of cadmium-induced liver injury in senescent male fischer 344 rats: role of Kupffer cells and inflammatory cytokines. Toxicol Appl Pharmacol 2000;162:68-75. [PubMed: 10631129]

Yoon P, Keylock KT, Hartman ME, Freund GG, Woods JA. Macrophage hypo-responsiveness to interferon-gamma in aged mice is associated with impaired signaling through Jak-STAT. Mech Ageing Dev 2004;125:137-43. [PubMed: 15037019]

Zhang Y, Wallace DL, de Lara CM, Ghattas H, Asquith B, Worth A, Griffin GE, Taylor GP, Tough DF, Beverley PC, Macallan DC. In vivo kinetics of human natural killer cells: the effects of ageing and acute and chronic viral infection. Immunology 2007;121:258-65. [PubMed: 17346281] 


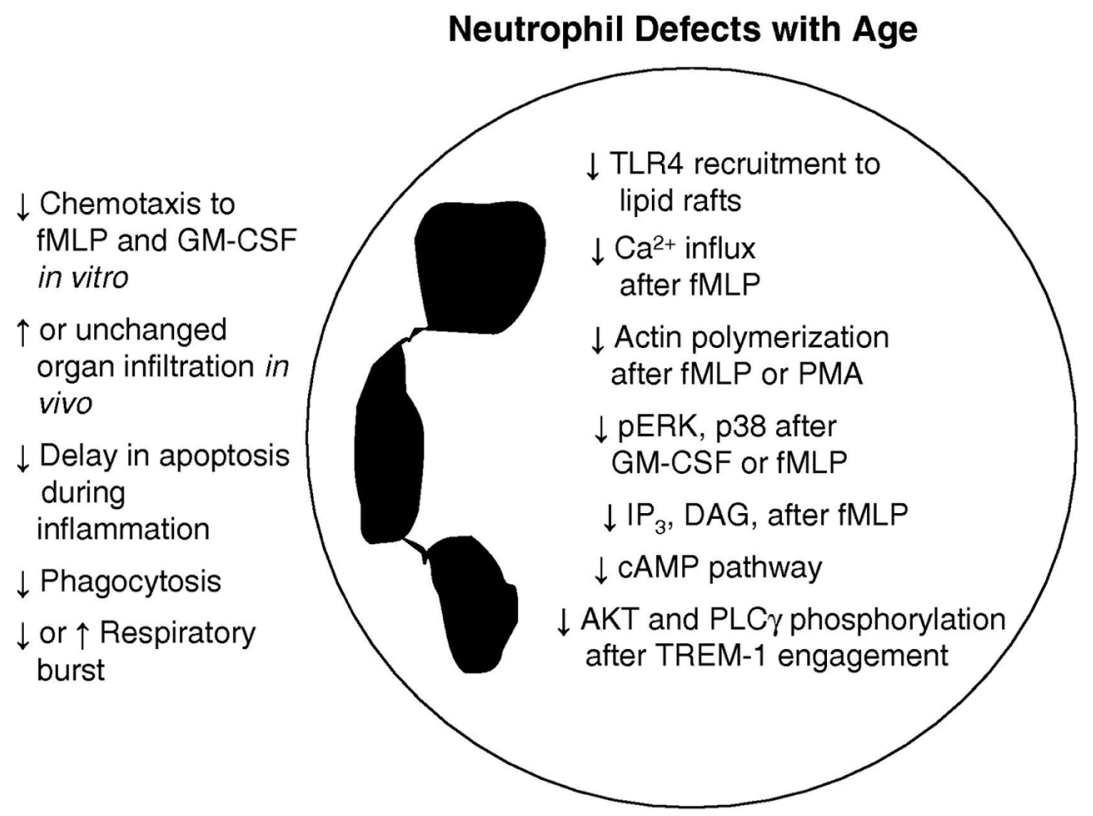

Figure 1.

Abbreviations: fMLP: N-formyl-methionyl-leucyl-phenylalanine; GM-CSF: granulocyte monocyte colony stimulating factor; TLR4: toll-like receptor 4; PMA: phorbol myristate acetate; ERK: extracellular signal regulated kinase; $\mathrm{IP}_{3}$ : inositol triphosphate; DAG: diacyl glycerol; cAMP: cyclic adenosine monophosphate; pTREM-1: triggering receptor expressed on myeloid cell-1. 


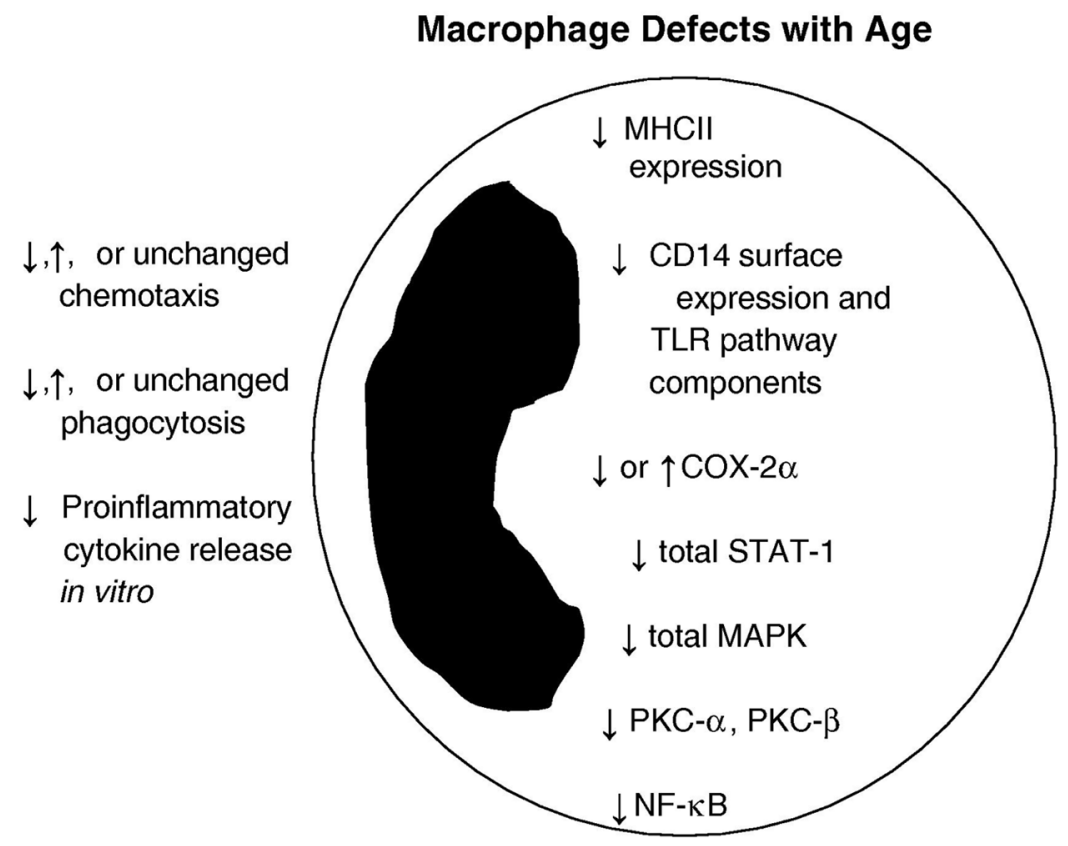

Figure 2.

Abbreviations: MHCII: major histocompatibility complex II; CD14: cluster of differentiation 14; TLR: toll-like receptor; COX-2: cyclooxygenase-2; STAT-1 $\alpha$ : signal transducer and activator of transcription-1 alpha; MAPK: mitogen activated protein kinase; PKC: protein kinase $\mathrm{C}$; NF- $\kappa \mathrm{B}$ : nuclear factor-kappaB. 
Table 1

Effects of aging on NK, NKT, mast cells and eosinophils

\begin{tabular}{|c|c|c|}
\hline Cell type & Change with advanced age & References \\
\hline \multirow[t]{5}{*}{ NK cells } & $\uparrow$ numbers in circulation & $\begin{array}{l}\text { (Mariani et al., 2001; Ogata et al., 1997; Solana and } \\
\text { Mariani. 2000) }\end{array}$ \\
\hline & $\downarrow$ activity & (Albright and Albright, 1983) \\
\hline & $\downarrow$ cytotoxicity & $\begin{array}{l}\text { (Mysliwska et al., 1992a; Mysliwska et al., 1992b; } \\
\text { Ogata et al., 1997) }\end{array}$ \\
\hline & Intact $\mathrm{ADCC}$ & (Fernandes and Gupta, 1981) \\
\hline & $\downarrow$ proliferation and IFN- $\gamma$ production in response to IL- 2 & (Borrego et al., 1999) \\
\hline \multirow[t]{6}{*}{ NKT cells } & $\uparrow$ numbers in lymphoid organs and blood & $\begin{array}{l}\text { (Dubey et al., 2000; Faunce et al., 2005; Ishimoto et al. } \\
\text { 2004; Poynter et al., 1997) }\end{array}$ \\
\hline & Contribute to age-associated: & \\
\hline & $\downarrow$ in vitro $T$ cell proliferation & (Faunce et al., 2005) \\
\hline & $\downarrow$ in vivo DTH & (Faunce et al., 2005) \\
\hline & $\uparrow \mathrm{IL}-10$ and IL-4 & (Faunce et al., 2005; Poynter et al., 1997) \\
\hline & $\downarrow$ cytotoxicity & (Mocchegiani et al.. 2004: Tsukahara et al.. 1997) \\
\hline \multirow[t]{3}{*}{ Mast cells } & $\downarrow$ numbers in the skin of humans & (Montagna and Carlisle, 1990) \\
\hline & $\uparrow$ numbers in the skin of BALB/c mice; no change in C57BL/6 mice & (Hart et al., 1999; Nguyen et al., 2005) \\
\hline & $\uparrow$ degranulation in varicose disease & (Pascual et al., 2007) \\
\hline \multirow[t]{5}{*}{ Eosinophils } & No change in cell number in sputum & (Vignola et al., 2003) \\
\hline & $\downarrow$ release of EDN in response to IL-5 in asthma patients & (Mathur et al., 2008) \\
\hline & $\downarrow$ release of EDN in response to fMLP & (Mathur et al., 2008) \\
\hline & $\downarrow$ production of $\mathrm{O}_{2}^{-}$in response to PMA & (Mathur et al., 2008) \\
\hline & No change in adhesion or chemotaxis in asthma patients & (Mathur et al., 2008) \\
\hline
\end{tabular}

Abbreviations: NK: natural killer; ADCC: antibody-dependent cell mediated cytotoxicity; IFN: interferon; IL: interleukin; NKT: natural killer T; DTH: delayed-type hypersensitivity; EDN: eosinophil-derived neurotoxin; fMLP: formyl-methionyl-leucyl-phenylalanine; $\mathrm{O}_{2}^{-}$: superoxide; PMA: phorbol myristate acetate. 